\title{
Factors influencing energy demand in dairy farming
}

\author{
S. Kraatz ${ }^{\#}$ W. Berg and R. Brunsch \\ Leibniz Institute for Agricultural Engineering Potsdam-Bornim e. V. (ATB), Max-Eyth-Allee 100, 14469 Potsdam, \\ Germany
}

\begin{abstract}
The efficiency of energy utilization is one of the key indicators for developing more sustainable agricultural practices. Factors influencing the energy demand in dairy farming are the cumulative energy demand for feed-supply, milk yield as well as the replacement rate of cows. The energy demand of dairy farming is assessed on the basis of direct and indirect energy inputs. The comparison of different replacement rates and milk yields shows clearly that both have a considerable influence on the energy intensity of dairy farming. The feed energy requirement $/ \mathrm{kg}$ milk produced is decreased with an increase in individual performance of the animals. Nevertheless, this effect diminishes gradually with milk yields higher than $8000 \mathrm{~kg} / \mathrm{cow} /$ year. Additionally, energy demand increases with higher replacement rates of cows. Milk yields higher than $8000 \mathrm{~kg} / \mathrm{cow} / \mathrm{year}$ can clearly not compensate for the increase in the cumulative energy demand. Therefore milk yields considerably higher than $8000 \mathrm{~kg} / \mathrm{cow} / \mathrm{year}$ are not advisable from the viewpoint of the cumulative energy demand for feed-supply. A decreasing service life of the dairy cows (increasing replacement rate) causes a higher energy demand per $\mathrm{kg}$ milk, but its influence is only marginal.
\end{abstract}

Keywords: Energy balance, milk production, milk yield, replacement rate, sustainability

\# Corresponding author: E-mail: sikraatz@atb-potsdam.de

\section{Introduction}

Energy resources are essential ingredients of global economic growth and development (Goldemberg, 1995). In agricultural practices a constantly growing consumption of raw materials and fossil energy due to the intensification and mechanisation of production technologies is recorded. In general, dairy products are luxury items and countries with sufficient affluence to consider dairy production will generally have succeeded in providing basic energy requirements to their population through improved crop yields and increased fertilizer and pesticide use (Roche \& Edmeades, 2004). But the increase of yields is not to be estimated as adequate to the increase of energy input in the procedures (Pimentel et. al., 1973). Efficient energy use by the agricultural sector is one of the conditions to ensure sustainable agriculture since it allows for financial savings, the preservation of fossil resources and a decrease in air pollution (Pervanchon et al., 2002). So far insufficient knowledge is available about the energy efficiency of production technologies in livestock production systems and how targets and intensity of production may influence the energy efficiency.

The purpose of this investigation was to determine how milk yields and productive life of the dairy cows influence the energy efficiency of dairy farming.

\section{Materials and Methods}

The calculations include the determination of the cumulative energy demand for forage production which relates to the direct and indirect energy inputs. These calculations include the cumulative energy demand for feed supply of adult dairy cows, as well as during the growing up period of heifers. The energy intensity is expressed as the energy demand per kg product produced.

The method used to determine energy input in the procedures of forage production is based on the VDI guideline 4600 "Cumulative energy demand - terms, definitions, methods of calculation" (VDI, 1997). The cumulative energy demand (CED) states the entire demand, value as primary energy, which arises in connection with the production, use and disposal of an economic good or which may be attributed respectively to it in causal relation. This energy demand represents the sum of the cumulative energy demands for the production $\left(C E D_{P}\right)$, for the use $\left(C E D_{U}\right)$ and for the disposal $\left(C E D_{D}\right)$ of the economic good (formula 1). 


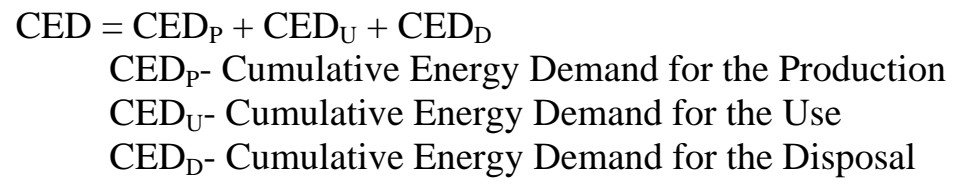

The investigation of the cumulative energy demand for forage production relates to typical site conditions of North-East-Germany with loamy sand soil. The calculation includes the direct energy input in the form of fuel oil, e.g. diesel fuel as well as indirect energy which includes the energy input for resources, manufacturing machinery and technical equipment (e.g. fertilizer, seed, pesticide, machinery).

The cumulative energy demand for the supply of on-farm feed is calculated by using the REPRO (Reproduction of soil fertility) model of (Küstermann et al., 2008). The whole procedure of plant production is estimated while including the procedure sections tillage, seeding, fertilization, plant protection, harvest and transportation as well as conservation.

Different diets according to various milk yields are calculated as total mixed rations (TMR's). Therefore the requirements of the dairy cow regarding a performance orientated feeding with the parameter net energy lactation $\left(\mathrm{NE}_{\mathrm{L}}\right)$ and usable crude protein (CP) as well as a balanced and ruminant appropriate feeding with the parameters fibre content (XF $>18 \%$ ), ruminal nitrogen balance (RNB $\geq 0 \mathrm{~g} / \mathrm{MJ}$ ME) and dry matter intake (DMI) are considered (Spiekers \& Potthast, 2004). Therefore $37.7 \mathrm{MJ} \mathrm{NE} / \mathrm{cow} /$ day and $450 \mathrm{~g}$ $\mathrm{CP} /$ cow/day are used for the maintenance of a $650 \mathrm{~kg}$ Holstein Friesian cow, while $3.3 \mathrm{MJ} \mathrm{NE} / \mathrm{kg}$ milk and $85 \mathrm{~g} \mathrm{CP} / \mathrm{kg}$ milk produced are respectively required.

The calculations envelop a range of replacement rates from $10 \%$ (lower extreme value) up to $50 \%$ (upper extreme value). The growing-up period of the heifers is 25 months (Spiekers \& Potthast, 2004). The growing-up period of the heifer can be related to the dairy cow in dependence on the replacement rate according to formula 2 (data see Table 1 ):

$$
\begin{aligned}
& \mathrm{RPC}=\frac{\mathrm{GP} \times \mathrm{RR}}{100} \\
& \mathrm{GP}=\text { growing up period of the heifers [months] } \\
& \mathrm{RR}=\text { replacement rate [\%] } \\
& \mathrm{RPC}=\text { rearing period per cow and year [months] }
\end{aligned}
$$

Table 1 Rearing period per cow in a year in dependence on the replacement rate (growing up period of the heifers is 25 months)

\begin{tabular}{cccccccccc}
\hline $\begin{array}{c}\text { Replacement } \\
\text { rate [\%] }\end{array}$ & 10 & 15 & 20 & 25 & 30 & 35 & 40 & 45 & 50 \\
$\begin{array}{c}\text { Rearing period } \\
\text { per cow and year } \\
\text { [months] }\end{array}$ & 2.5 & 3.8 & 5.0 & 6.3 & 7.5 & 8.8 & 10.0 & 11.3 & 12.5 \\
\hline
\end{tabular}

\section{Results and Discussion}

The cumulative energy demand for feed supply as calculated for the fundamental ration ingredients is shown in Table 2. The production of concentrate feeds needs a higher cumulative energy demand per kg dry matter than the production of roughage feed. The proportions between the feeds are different when the cumulative energy demand is related to net energy lactation $\left(\mathrm{NE}_{\mathrm{L}}\right)$ or usable crude protein $(\mathrm{CP})$. Maize silage has the lowest cumulative energy demand for all three reference bases except pasture. Pasture requires in all cases the lowest cumulative energy demand because almost no machines are used. 
Table 2 Nitrogen fertilizer, yields and cumulative energy demand for the provision of different roughage feeds and Triticale

\begin{tabular}{|c|c|c|c|c|c|c|}
\hline Feedstuff & $\begin{array}{c}\text { Nitrogen fertilizer } \\
\text { kg N/ha }\end{array}$ & $\begin{array}{c}\mathrm{DMY}^{\mathrm{a}} \\
\mathrm{t} / \mathrm{ha}\end{array}$ & $\begin{array}{l}\text { CED }^{\mathrm{b}} \\
\mathrm{MJ} / \mathrm{ha}\end{array}$ & $\begin{array}{c}\text { CED }^{b} \\
\mathrm{MJ} / \mathrm{kg} \text { DM }\end{array}$ & 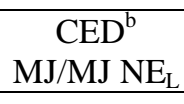 & $\begin{array}{c}\mathrm{CED}^{\mathrm{b}} \\
\mathrm{MJ} / \mathrm{kg} \mathrm{CP}\end{array}$ \\
\hline Maize silage & 132 & 11 & $18^{\mathrm{c}}$ & $1.66^{\mathrm{c}}$ & $0.259^{c}$ & $0.013^{c}$ \\
\hline Triticale & 135 & 5 & 13 & 2.64 & 0.318 & 0.016 \\
\hline Grass silage $^{\mathrm{d}}$ & 65 & 7 & $14^{\mathrm{e}}$ & $1.99^{\mathrm{e}}$ & $0.326^{\mathrm{e}}$ & $0.015^{\mathrm{e}}$ \\
\hline Pasture & 80 & 6 & 5 & 0.84 & 0.131 & 0.006 \\
\hline Hay $^{f}$ & 74 & 7 & $12^{\mathrm{g}}$ & $1.78^{\mathrm{g}}$ & $0.336^{\mathrm{g}}$ & $0.015^{\mathrm{g}}$ \\
\hline
\end{tabular}

${ }^{\mathrm{a}}$ Dry matter yield, ${ }^{\mathrm{b}}$ Cumulative energy demand, ${ }^{\mathrm{c}} 15 \%$ losses, ${ }^{\mathrm{d}} 3$ cuts, ${ }^{\mathrm{e}} 20 \%$ losses, ${ }^{\mathrm{f}} 2$ cuts, ${ }^{\mathrm{g}} 30 \%$ losses.

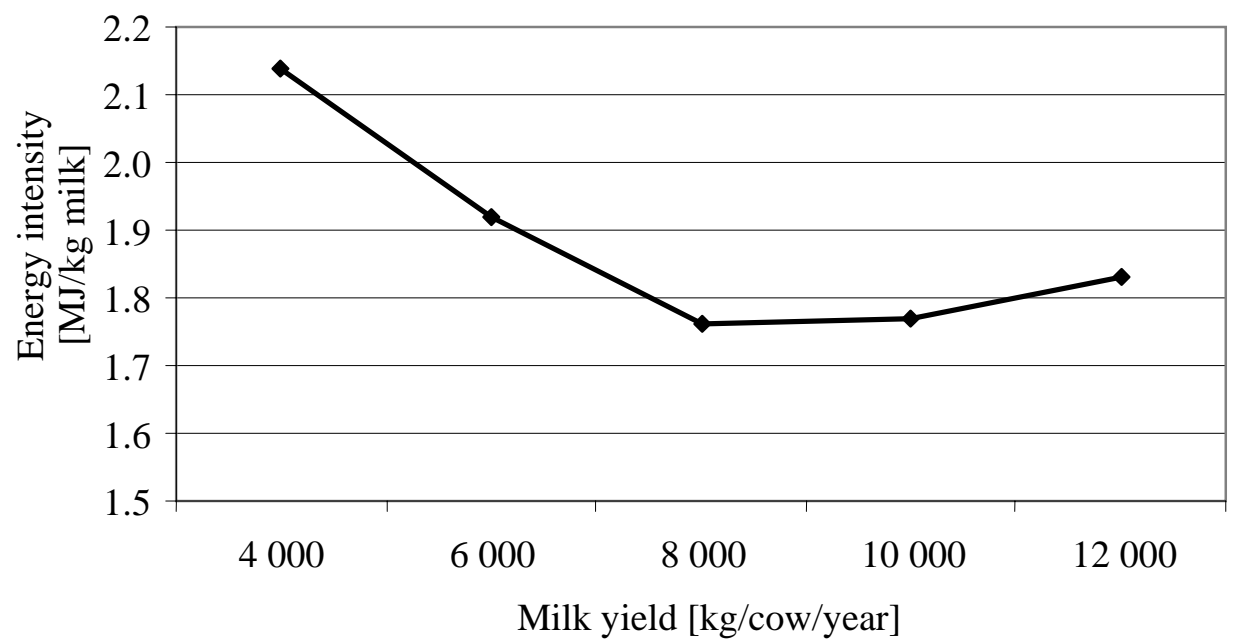

Part of concentrate in the diet (in \% of DMI):

17\% - $4000 \mathrm{~kg}$ milk/cow/year; 23\% - $6000 \mathrm{~kg}$ milk/cow/year; 27\% - 8000 kg milk/cow/year;

34\% - $10000 \mathrm{~kg}$ milk/cow/year; 38\% - $12000 \mathrm{~kg}$ milk/cow year.

Figure 1 Energy intensity for feed supply in dairy farming in dependence on different milk yields without consideration of replacement rates.

Besides the production of single feeds, the composition of the diet is important for the energy intensity of dairy farming (Kraatz et al., 2006). With increasing milk yields, the energy requirement of cows increases and it must be met by an increase in the energy concentration of the diet.

The energy demand for feed/kg of milk produced (energy intensity) decreases with milk yields between $4000 \mathrm{~kg}$ and $8000 \mathrm{~kg}$ per cow/year (Figure 1). With higher milk yields this effect is less or contrary (>10 $000 \mathrm{~kg} / \mathrm{cow} / \mathrm{year}$ ). The increasing milk yields cannot compensate for the higher cumulative energy demand anymore, because of the increasing share of concentrates in the diet.

The influence of different replacement rates and milk yields on the energy intensity of feed supply in dairy farming is shown in Figure 2. These results indicate that with an increase in milk yield, the energy intensity for feed supply per cow decreases. However, for higher milk yields (8 $000 \mathrm{~kg} / \mathrm{cow} / \mathrm{year}$ with a replacement rate of $<30 \%$ or $10000 \mathrm{~kg} / \mathrm{cow} /$ year with a replacement rate of $>30 \%$ ) this effect decreases. The energy intensity for feed supply rises almost linearly with an increased replacement rate, irrespective of milk yield. The comparison of the different replacement rates and milk yields shows that both have a considerable influence on the energy intensity of feed supply. For example the energy intensity of feed supply for the production of one $\mathrm{kg}$ milk with an average milk yield of $6000 \mathrm{~kg} / \mathrm{cow} /$ year and a replacement rate of $20 \%$ is 
in the same range of that for a milk yield of $8000 \mathrm{~kg} / \mathrm{cow} /$ year and a replacement rate of $40 \%$ as well as that with a milk yield of $10000 \mathrm{~kg} / \mathrm{cow} /$ year and a replacement rate of $50 \%$, respectively. Generally the replacement rate is increasing with an increase in milk yield.

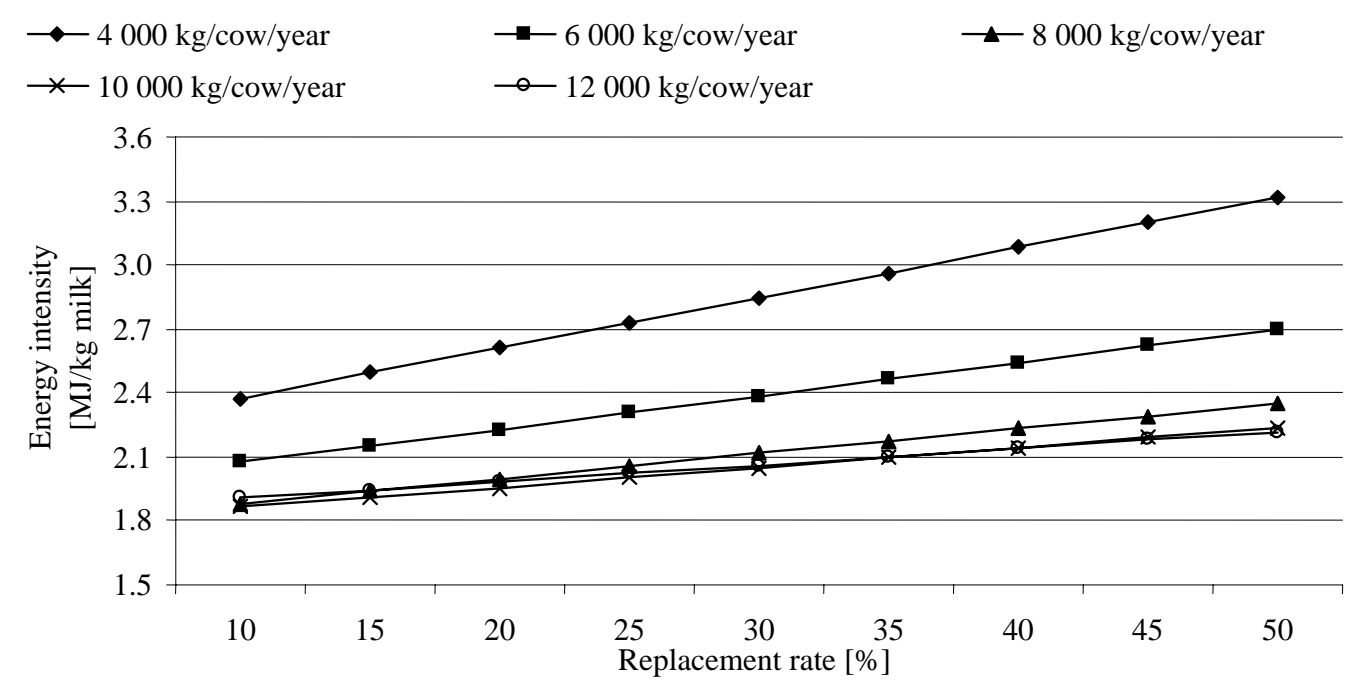

Figure 2 Energy intensity for feed supply in dependence on different replacement rates and milk yields.

\section{Conclusion}

Cumulative energy demand for feed supply in dairy farming increases with an increase in milk yield and replacement rate. Whereas, energy intensity (cumulative energy demand/kg milk produced) decreases with increasing milk yields to a range of 8000 to $10000 \mathrm{~kg} / \mathrm{cow} /$ year. Milk yields above this range effect only a slight increase of energy intensity.

\section{Acknowledgements} tion (DBU).

The authors gratefully acknowledge support provided by the German Federal Environmental Founda-

\section{References}

Goldemberg, J., 1995. Energy needs in developing countries and sustainability. Science 269, 1058-1059.

Kraatz, S., Berg, W., Küstermann, B. \& Hülsbergen, K.-J., 2006. Energy and Carbon Balancing in Livestock Keeping. World Congress Agricultural Engineering for a Better World, Bonn, 3.-7.9.2006, Düsseldorf, VDI Verlag GmbH, Nr. 1958.

Küstermann, B., Kainz, M. \& Hülsbergen, K.-J., 2008. Modeling carbon cycles and estimation of greenhouse gas emissions from organic and conventional farming systems. Renewable agriculture and food systems, Vol. 23 (1), 38-52.

Pervanchon, F., Bockstaller, C. \& Girardin, P., 2002. Assessment of energy use in arable farming systems by means of an agro-ecological indicator: the energy indicator. Agricultural Systems, Vol. 72, Number 2, 149-172 (24).

Pimentel, D., Hurd, L.E., Bellotti, A.C., Forster, M.J., Oka, I.N., Sholes, O.D. \& Whitman, R.J., 1973. Food production and the energy crisis. Science 182, 443-449.

Spiekers, H. \& Potthast, V., 2004. Successful Feeding of Dairy Cows. (Erfolgreiche Milchviehfütterung.) 4. völlig neu überarbeitete Auflage, Frankfurt am Main, DLG-Verlags-GmbH (in German).

Roche, J.R. \& Edmeades, D.C., 2004. The paradigm of efficiency and sustainability - a dairying perspective. S. Afr. J. Anim Sci. Vol. 34 (Suppl. 2), 8-16.

VDI, 1997. VDI guideline 4600 - Cumulative Energy Demand - Terms, Definition, Methods of Calculation. Verein Deutscher Ingenieure (Association of German Engineers), Düsseldorf (in English and German). 